\title{
VANISHED HISTORY: \\ REPRESENTATION OF HISTORY OF INDIGENOUS PEOPLE IN THE ONTARIO SOCIAL STUDIES CURRICULUM (GRADES 9-12)
}

\section{Evgeniya Bobrovnik}

This article is a document analysis of the Ontario secondary Social Studies curriculum, specifically, of how it represents the history of Indigenous people. The analysis revealed omissions in representation, and limitations in perspective concerning the Indigenous population in history and current events. Applying the framework of antiracist pedagogy and Culturally Responsive Teaching practices, the author suggests that thorough representation of indigenous history in the curriculum plays an integral role in anti-racist education and proposes ways to overcome curriculum limitations.

Keywords: anti-racist pedagogy, indigenous history, Ontario secondary curriculum

As an educator, a teacher must teach about past and recent events and must try to present the complete story while doing so. A teacher wants his or her students to have a factual understanding of the history of Indigenous people in Canada, including knowledge of the Residential School System. She or he relies on curriculum documents and a textbook. Is this reliance justified? Does the Ontario history curriculum represent the complete history of Indigenous people? How are these events portrayed and investigated in the curriculum? If these resources are lacking, what are some ways educators can overcome a limited coverage of indigenous history in the curriculum? These are some of the questions addressed in this research paper.

It is the position of this researcher that schools, educators, and the government need to accept responsibility for promoting respect and awareness regarding the treatment of Indigenous people as well as other groups that experienced discrimination, prejudice, and outright racism at the hands of society and the government. Further, she contends that if the curriculum does not adequately address this responsibility, then students will get their knowledge of these histories elsewhere, which may lead to absorbing half-truths, pseudohistory, and misinformation.

\section{Literature Review}

The subject of teaching the truth about the Residential schools and similar aspects of Canadian history has received a lot of attention and the Calls for Action (2015) was published 
because of the Canadian Truth and Reconciliation Commission (TRC) findings (2015). How fully are the TRC's findings and recommendations reflected in the curriculum taught in the public education system? A limited amount of research has been conducted on the amount and the quality of indigenous content representations in the Ontario curriculum. The current research shows that "most student engagement with aboriginal history is construed in a highly historic nature, portrayed through the lens of interaction in relation to European history" (Godlewska, Moore, \& Bednasek, 2010, p. 419).Even though there are courses--Native Studies and Native Languages--offered as electives for both academic and workplace streams in grades 9-12, there is no data on the number of schools in Ontario that offer these courses. In this research paper, I focus my analysis on the government educational policies, curriculum documents, and published works including but not limited to: Battiste (1995-2013), Dei (2013), Godlewska et al. (2010), Laenui (2000), LeBlanc (2012), and Longboat (1987).

The history of treaties since 1870 s to 2000 s, effectively summarised by Carr-Stewart (2001), describe the lack of fulfillment of state responsibilities on a number of occasions, specifically in relation to education: "during Canada's century of avoidance of the treaties, First Nations people kept the treaties alive and continued to press, from time to time, for the fulfilment of the treaty promises, particularly the treaty right to education" (p. 138).

The analysis of these researches shows the consequences of racial discrimination against Indigenous people, including but not limited to events related to the Canadian Residential School System. Such discrimination was recently acknowledged by the Canadian government. The official apology issued by the Ministry of Indian Affairs in 1998 admitted that previous actions have led to: "the erosion of the political, economic and social systems of Aboriginal people and nations" (Indigenous and Northern Affairs of Canada, 1998).

In 2015, the Summary of the Final Report of the TRC was published. It shed light on history of the wrong doings against Indigenous people in Canada, including the memories of survivors. Our knowledge of incidents of discrimination against Indigenous people is limited to the published proceedings of the TRC and survivors ' narratives. The Summary of the TRC report Honouring the truth, reconciling for the future (2015) says:

For over a century, the central goals of Canada's Aboriginal policy were to eliminate Aboriginal governments; ignore Aboriginal rights; terminate the Treaties; and, through a process of assimilation, cause Aboriginal peoples to cease to exist as distinct legal, social, cultural, religious, and racial entities in Canada. The establishment and operation of residential schools were a central element of this policy, which can best be described as "cultural genocide" (p. 1).

The TRC Final report (2015) talks about the 1) genocide of Indigenous people, deprivation of land, displaced persons and children, reserves, and cultural genocide (destruction of language and belief systems) have had a lasting historical and social impact. It has resulted in Indigenous inter-generational trauma; racism and discrimination of Indigenous people through stigmatization and the deprivation of education and other social services (e.g. 
medical). These impacts have been felt for over a century and still influence perceptions of Indigenous people and social affect Indigenous - nonIndigenous interactions. Analysis of the ways such actions and impacts are currently represented in the Ontario History curriculum are described in the Findings section of this paper.

It must be noted that the Ontario History curriculum was written prior to the release of the TRC findings and that public attention given to the discrimination of Indigenous populations in Canada is recent. Nevertheless, students and educators need to learn and teach, respectively, about such forms of racism. Current events in Canada cannot be fully understood without having an educated grasp of how Indigenous people have faced discrimination since colonization, and how they and Canadian society, continue to feel the effects of colonization to this day (land disputes, missing Indigenous women, education gap between Indigenous and non-Indigenous students). By attempting to teach about and reconcile with the aftermath of discrimination against Indigenous people, it may be possible to confront manifestations of racism towards other marginalized groups. It is the view of this researcher that study units on residential schooling should be powerful enough to act as a deterrent against all forms of racism in our society. That is, one study of anti-racism may be applicable to other various forms of racism and should increase students' understanding of racism and encourage students to be openly and pro-actively anti-racist and acknowledge the legacy of colonization in Canada.

\section{Conceptual Framework}

This paper uses document analysis to research representations of Indigenous people in the Ontario History curriculum (see Appendix A) within a multiple racism and anti-racism framework (Stanley, 2014). The purpose of this research paper is to determine if a thorough historical representation is available in curriculum resources for educating future citizens and if not, to suggest modified curriculum resources to inform learning expectations and teaching practices when addressing difficult topics, namely discrimination against Indigenous people in Canada.

The findings of this qualitative curriculum analysis are reviewed using Stanley`s (2009, 2014) framework of multiple racisms and anti-racisms. As Stanley suggests, racism involves three distinct characteristics: racialization, exclusion, and consequences (Stanley, 2014, p. 6). Should this document analysis show omissions of essential historical events in the curriculum, especially incidents of discrimination against Indigenous people, such omissions will be interpreted as constituting racializations and exclusions which make the curriculum part of the "racism configuration" (Stanley, 2014, p.6). According to Stanley (2014), "racisms can have different configurations-institutional, economic, epistemological, ontological, and so on" (p.7). Analyzing racisms allows for the development of antiracist strategies: "antiracisms can in practice address any one or all of the conditions for racisms; specifically, they can challenge racializations, foster deracialized inclusions, and/or mitigate negative consequences" (Stanley, 2014 , p. 6). Drawing from the antiracisms described in the article by Stanley (2014), I suggest changes to the curriculum and further research of historic representations of Indigenous issues in curricula and textbooks (Blakeney, 2005). Another possible antiracism involves speculations 
about whether the current history curriculum meets the general curriculum objectives related to the education of good citizens as mandated in the Citizenship Education Framework by the Ontario Ministry of Education (2013).

\section{Research Questions}

Curriculum documents tend to articulate a very narrow aspect of peoples' lived histories that are silenced through these omissions. I argue that historical racisms are not presented accurately in the curriculum, and only a partial picture is painted. Based on my initial review of the curriculum documents and the historical facts acknowledged by the TRC findings, representation of the history of Indigenous people in Canada is short and misleading. It is up to the discretion of the educator on how much time is to be spent teaching this topic. This paper addresses the following questions:

1. How is discrimination against Indigenous people remembered in Ontario secondary school history curriculum documents?

2. What is the impact of teaching history through such a limited and exclusive perspective?

3. How can teachers overcome such exclusions in the curriculum?

It is important to consider whether the perspectives shown only represent the perpetrators' narratives, to consider how often the victim's perspectives are represented, and to consider what terminology is being used, and determine if the terminology is problematic.

The initial review showed that the Residential School system, as a piece of history, does not receive a sufficient amount of attention or critical study in the curriculum. If the results of this research show that Indigenous history is not represented adequately in the curriculum, it is hoped that this paper might effect change in current curriculum development and encourage dialogue about the subject.

\section{Methodology and Data Collection}

Qualitative document analysis is the main method used in this research. The data studied includes Ontario curriculum documents (Social Studies Grades 9-12), the latest Ontario Ministry of Education policies regarding Indigenous knowledge, and TRC published reports.

The Ontario Grade 9-12 selected courses in the History curriculum, namely learning objectives, expectations, and questions for discussion, were analyzed by counting occurrences of themes related to the history of Indigenous people in Canada. For a complete list of curriculum documents being investigated, as well as specific courses, please see Appendix A. Call for Action and the Final Report published by the TRC in 2015 have inspired me to research how the history of Indigenous people is represented in the Ontario curriculum. 
The following themes occurred when reading both TRC reports and curriculum documents: terminology used as well as coverage of the residential schools' history and the history of Treaties. Findings are presented in a table with the analysis of the major omissions (see Appendix B). Recommendations to address exclusions of the essential historic facts and approaches to teach difficult knowledge may help educators to overcome the limitations of the current curriculum.

\section{Findings}

This work is like dropping a stone in the water. We are creating ripples and eventually all people will find themselves in the circle.

Albert Scott-Nakawé Traditional Knowledge Keeper, Kinistin First Nation

This part of the paper addresses the questions of how accurately the history of Indigenous people is described in Ontario secondary curriculum documents, and of the kind of impact such description might have. Before proceeding to my analysis of the Ontario Social Studies curriculum documents for grades 9-12, I would like to position myself as an immigrant, living on unceded Algonquin land, studying and conducting my research at the University of Ottawa located on unceded Algonquin land. I was involved in research projects related to the Indigenous people of the Russian Far East and see this document analysis as a continuation of my personal research interests. I feel privileged to be able to contribute to the evaluation of the current Ontario curriculum.

Reading the Official Apology by the Ministry of Indian Affairs (1998), we learnt that:

As a country, we are burdened by past actions that resulted in weakening the identity of Aboriginal peoples, suppressing their languages and cultures, and outlawing spiritual practices. We must recognize the impact of these actions on the once self-sustaining nations that were disaggregated, disrupted, limited or even destroyed by the dispossession of traditional territory, by the relocation of Aboriginal people, and by some provisions of the Indian Act. We must acknowledge that the result of these actions was the erosion of the political, economic and social systems of Aboriginal people and nations (Indigenous and Northern Affairs of Canada, 1998).

The findings of TRC (2015) echo a statement made by the Ministry of Indian Affairs in 1998 acknowledging attitudes of racial and cultural superiority and the suppression of Aboriginal culture and values. More public attention has been drawn to the history of Indigenous people over the past years, but the curriculum still needs a more thorough coverage of these subjects, such as the history of Treaties. As outlined by indigenous researchers and researchers of Indigenous matters (Battiste, 20083-2013; Dei, 2013; Donald, 2009), European settlers were expected to respect the treaties initially agreed upon and were expected to keep their promises to provide social services including education. History, however, has witnessed "ruthless marginalization of the First Nations on the southern prairies through governmentorganized famine, military actions and total bureaucratic control over their lives" (Daschuk, 
2013). Battiste (2004), for example, talks about the transformation of cooperative relationships (outlined in the treaties) into oppressive residential schools "built on negative stereotypical mythic representations of Indians...and Eurocentric glorification" (p. 3). The question of how much we know today about the mistreatments that happened in the recent past remains; the answer is directly linked to the public-school curriculum.

Table B1 in Appendix B was compiled analyzing the curriculum documents of the five courses outlined in Appendix A using a mixed research method. I counted over 66 pages and nearly 100 learning expectations in total. Every learning goal and expectation was scanned for lexical phrases containing references to residential schools, treaties, Indigenous affairs, interactions, and organizations.

\section{Terminology Used}

The analysis shows that the following terms: First Nations, Inuit, and Métis are not present and are not suggested for discussion and exploration. The document uses the term "aboriginal" rather than Indigenous, and the term does not necessarily include all Indigenous populations. There are no learning expectations about the history, geography, or social institutions in Canada prior to European settlers in secondary school curriculum documents. The first interactions between settlers and indigenous people are studied in grades 6 and 8 (Godlewska et al., 2010). The history of Indigenous people is washed out of all grades in the curriculum and of the Ontario public educational system. Canadian history represents privileged settler perspectives on events and provides limited coverage of the Indigenous issues.

\section{Curriculum}

There are four specific learning expectations, of the nearly 100 expectations in the five courses analysed, dedicated to historical events related to Indigenous populations in Canada; most of them are limited to describing interactions between the federal government and Indigenous people. Most of the suggested questions and themes relevant to Indigenous people are offered as one of the many possible examples or prompt questions listed for certain learning expectations. It is ultimately up to the teachers ' personal judgement to ask their students to analyse the history of Indigenous affairs, or not to if they select other questions. As a teacher, I can attest that learning materials on world/international affairs are readily and widely available, while obtaining learning materials on Indigenous issues require greater effort to locate. This, of course, raises the issue of how to get access to available educational resources about Indigenous history, and how to make these resources available to teachers in $\mathrm{K}-12$ public education system.

\section{Residential Schooling Representation}

The five analyzed courses, about 66 pages of 100 learning objectives and expectations, contained the phrase residential schools eight times. In one such case, the curriculum associated residential schools with boarding schools in connection to the role religion plays in historical events. The course World History Since 1900: Global and Regional Interactions 
(CHT3O) contains the most number of the learning expectations, five out of eight, related to residential schools, suggesting students compare, and contrast residential schooling systems to boarding schools used in various parts of the world and discuss the role of religion in governing boarding schools in Canada. For example, the learning expectation C3.1 suggests that students answer the question, "how residential schools in Canada and Australia violated the rights of aboriginal peoples?" Expectation D2.5 asks students to discuss "the role of religion in operating boarding schools for Indigenous children in Canada" (The Ontario curriculum grades 11 and 12: Canadian and World Studies, p. 363). The phrasing of the expectation D2.5 fails to name the residential schools properly, opting for a neutral term 'boarding schools'. It also fails to talk about the suppressing role of religious organizations in placing Indigenous children in the residential schooling system. Revealing half of the truth does not represent the full historical picture to our students. Half truths as represented in D2.5 limit students' understanding of the devastating long-term negative effects the residential schooling system still has on society discussed in the TRC and the existing research of the matter. "The multigenerational loss of parenting skills is just one of the many losses attributable to the strategy of 'assimilationthrough-education ' practiced by residential schools. It is little wonder that some Aboriginal communities view the school system as the agent of their oppression and are suspicious of its attempts to respond to Aboriginal students" (Robertson, 2003).

\section{Treaties and Indigenous Rights Representation}

I question the reasoning behind putting the inherent rights of Aboriginal people in single quotation marks in the curriculum expectation B2.1 for Civics and Citizenship course (CHV2O). Does it signify a citation, a doubt, or something else? If this was taken from a source, it should be cited, but it is not, so as readers question the meaning of the single quotation marks a certain amount of doubt and confusion is generated about the content of the quoted text. Does it mean that the rights of Aboriginal people are not deemed inherent or that their claims to legal rights to the land and resources stated in the treaties are unjustified?

As for the history of treaties, unlike other provinces, the Ontario Social Studies secondary curriculum occasionally mentions the existence of treaties without being specific. The mainstream Ontario curriculum mandates discussion of the Indian Act only once in a Grade 8 History course; The Development of Western Canada mentions it twice and only parenthetically. One of the parenthetical mentions is in a grade 11 course: Canadian History and Politics since 1945. (Godlewska, 2010, p. 420). Ontario has a lot to learn from, for example, Saskatchewan, where on December 10, 2007 the Saskatchewan government committed "to making instruction in history and content of the Treaties mandatory in the K-12 curriculum" (Saskatchewan Ministry of Education, 2009, p. 6).

The expectation B2.4 for the course CHV2O fails to state the ethnicity of the missing women openly, drawing attention instead to the issues of women in Canada, and in the process avoids telling the complete truth. Although the issue of missing and murdered Indigenous women is very recent, the curriculum needs to acknowledge the existing problem and to list various associations helping to raise awareness of these Indigenous women in Canada. 
The analysed curriculum mentions the Indian League twice without any reference to discrimination of Indigenous veterans, "who had fought in the war [but never] were not granted land as part of 'soldier's settlement'." Instead, they were confined to their own reserve land. In fact, when Indigenous veterans returned to their homes on reserves, many discovered that the government had purchased their land to sell it to the Soldier Settlement Board. This land was then sold to non-Indigenous veterans who wanted to become farmers" (Library and Archives Canada, 2008).

There is just one specific expectation mentioning the Truth and Reconciliation Commission (TRC) in CHT3O (E3.3), and one other expectation suggesting students discuss the ways Canada commemorates the wrongdoings of the past in CHC2P (E3.4). There are no references to the TRC findings and recommendations throughout the curriculum documents of the five analyzed courses. The curriculum documents do not suggest any ways students can engage in reconciliation practices in school or in a larger community.

Most of the learning expectations suggest discussion of issues related to Indigenous people in the past, without attempting to provide students with a historical continuum, thus depriving them of acquiring critical analytical skills about current and topical issues even though acquisition of such skills is outlined as mandatory in the Citizenship Education Framework (Appendix C). For example, expectations B1.2 and B1.5 for the course Adventures in World History (CHM4E) mention the historic migrations of Indigenous people to access natural resources before 1982, but do not offer any explanations as to why these events are not happening today. They do not ask students what impact this might have on current and future generations of Indigenous people.

The learning expectation C1.1 in CHM4E, again, talks about the past impact of the European settlers, but does not attempt to put this history in perspective or to question the extent to which those and recent events still influence Canadian society. Students ' historical thinking and analytical skills are at risk if the curriculum continues to engage students with indigenous history in a misrepresented way, that is, a highly historic nature portrayed through the lens of interaction in relation to European history (Godlewska, Moore, \& Bednasek, 2010).

Indigenous history in the curriculum focuses on the Eurocentric perpetrators' narratives' effectively silencing other narratives, and fails to portray other perspectives, such as the Indian League veterans of the War perspectives. Further, the curriculum rarely addresses current discrimination of Indigenous people so that students are not given the opportunity to make historical connections between the past and present. If students do not learn about Canadian history, including its darker aspects how can they become active citizens who can advocate for change and equity in society. Learning expectations do not offer students the opportunity to discuss complete stories, such as, racism against the Indigenous population, alcohol abuse, forced sterilization, and HIV mistreatment that occurred in the late 20th century. Teaching a limited perspective of the history of Indigenous people does not provide an accurate or explicit depiction of the past and is not sufficient to teach students critical thinking and analytical skills 
needed to comprehend the historical continuum of Canada even though acquisition of such skills is outlined as mandatory in the Citizenship Education Framework (see Appendix C).

Not revealing the complete truth and only telling history through one perspective allows for the continuation of a positive grand Settle narrative to prevail. The grand narrative is the most familiar and common story and is not a particularly good history. Limited perspectives of historic events reinforce social injustice and multiple racisms, denying younger generations the ability to critically assess history and bring about change for a better future.

\section{Recommendations}

The results of this research suggest the following four curricular recommendations related to perspectives, comprehensive glossary, female experiences, and Native Studies courses:

1. Representatives and respected Leaders of the First Nations, Inuit, and Métis people must be invited to take an active part in and contribute to the design of the school curriculum in the areas covering related historical and recent matters.

2. The recent accepted practice of using "Indigenous" as a more encompassing broader term should be used in curriculum documents.

3. The curriculum needs to make clear the names of organizations and associations active in voicing problems pertinent to Indigenous to provide students with up-to-date information relating to the historic and current position of Indigenous females in the society.

4. Native studies, as an integral part of Canadian history, must be introduced in practice.

\section{Perspectives}

Native voices about past events of colonization, forced relocation, misplacement, residential schools, and current issues of deteriorating natural resources viable to survival of local communities are not represented in the curriculum documents. Echoes of Residential Schooling that are felt through generations, leading to inter-generational trauma; high suicide rates; and the academic gap between Indigenous and non-Indigenous students - all the above are not depicted in the learning expectations.

\section{Comprehensive Glossary}

In regard to the terminology related to Indigenous matters, the curriculum does not define First Nations, Inuit, or Métis, nor does it mention that behind every term there are different languages, histories, and narratives. The word "Indigenous" is not used at all in the 
current curriculum, but rather the term "aboriginal" is used. "Aboriginal" is a term that does not include certain groups of people and is perceived offensive by some groups (Ward, 2015).

\section{Female Experiences}

Despite the issue of missing and murdered Indigenous women being a long and ongoing one, it has only recently received public attention. This researcher realises this might be one of the reasons it is not represented in the curriculum. However, such omission needs coverage and disclosure along with the discussion of the forced sterilization of Indigenous women that was carried out at the time of the Eugenics movement, supported by the first Canadian suffragettes. "Evidence indicates this practice was carried out by eugenically minded doctors in Ontario and northern Canada, where aboriginal women were the prime targets" (Porter, 2015). The Native Women's Association of Canada has been engaged in research on the issue of missing women and has published reports on the matter (NWAC, 2016).

\section{Native Studies}

The history of Indigenous people must be represented not only through scattered references to the past, but also through coverage of effects of past wrongdoings and present inequalities that persist in Canadian society. At the secondary level, three Native Studies courses (grades 10,11,12) have been developed and implemented in provincial schools. The courses are not just guidelines; they are very extensive, detailed, and created in a teacher friendly format. It is reported that many First Nations schools use these courses in varying degrees, adapting them to meet their needs or using them only as resource materials (Faries, 2002).

In Ontario, the secondary level Native Studies courses are not mandatory and are offered to students as electives. There is no published research about the number of schools offering Native Studies courses in practice. Teaching such courses is determined by local agreements and depends on the number of students enrolled. Though not part of this research, it has not been estimated how these planned courses reach the target audience and how extensive this audience is. As a sign of acknowledgement of incomplete representation of Indigenous history, in February 2016, Ontario government has made a commitment to a fuller representation of Indigenous issues, obliging government workers and pre-service teachers to learn about the past (Office of the Premier, 2016).

\section{Difficult Knowledge and Culturally Responsive Pedagogy}

Learning about some aspects of Indigenous history, such as residential schools, constitutes difficult knowledge that can be defined as "the representations of social traumas in curriculum and the individual's encounters with them in pedagogy" (Pitt \& Britzman, 2003, p. 755). Avoiding such knowledge, however, may lead to the marginalization of Indigenous youth. Battiste (2004) says: "approximately $68 \%$ of First Nations students are in provincial schools so provincial public educational systems must act on and recognize the tragic educational failure of residential schools and the effect it has on its peoples" (p. 4). Current educational policies 
must undergo substantive reform through rejection of the racism inherent to colonial systems of education, and reposition Indigenous humanities, sciences, and languages as vital fields of knowledge, as suggested by Battiste (2008-2013) in her numerous works. The urgency for this reform lies in the social, technological, and economic challenges facing society today, and the need for a revitalized knowledge system that incorporates both Indigenous and Eurocentric thinking (Battiste, 2013).

The problem of misrepresentation and a Eurocentric curriculum also exist in provinces other than Ontario. For example, the report on the survey conducted in Manitoba in 2003 emphasizes the need to move Aboriginal content and perspectives from the margins to the centre of the curriculum (Robertson, 2003). "Unless the bad news is made public, real improvement will be, at best exceptionally slow. Full and public disclosure will provide much greater incentive for improvement" (Cowley \& Easton, 2004, p. 5).

The good news is that the long-existing problem of partial representation of dark sides of the Canadian history is acknowledged by the government; not simply through reconciliation as a printed concept in the TRC, but by taking steps towards full description of incidences of the discrimination of Indigenous people in curriculum documents. For example, as of September 2015, Ontario's Faculties of Education are required to provide mandatory content that includes First Nation, Métis, and Inuit histories, cultures, perspectives, and ways of knowing. The changes are also to occur in the public schools ' curriculum. Bringing to action the Political Accord (see Appendix D) signed in August 2015, the provincial government as of February 17, 2016 addressed the Truth and Reconciliation Commission of Canada's (TRC) Calls to Action regarding education and training. It introduces mandatory Indigenous cultural competency and anti-racism training for every employee in the Ontario Public Service (OPS) and implements mandatory learning expectations in Ontario's public education system curriculum (Office of the Premier, 2016).

According to a recent press release by the federal government, in collaboration with First Nations, Métis, and Inuit communities and education partners, the Ministry of Education is developing a comprehensive plan to ensure that the impact of residential schools, the history of colonization, and the importance of treaties is incorporated into mandatory learning expectations in Ontario's public education system curriculum (Office of the Premier, 2016).

Teaching difficult knowledge and engaging Indigenous students in education may be solved by practicing a relatively new theory of Culturally Responsive Schooling (CRS). CRS aims at including the students, who are not part of a mainstream culture, in an education system that 'recognizes, respects, and uses students' identities and backgrounds as meaningful sources for creating optimal learning environments" (Castagno \& Brayboy, 2008, p. 947). Some of the practices include the presence of cultural leaders and advisors to lead ceremonies and reveal knowledge of the culture that for the most part is not in public domain, as well as First Nation and Métis staff who are powerful role models" (Part, 2008, p. 12).

The Ontario Ministry of Education (OME) created a framework for an inclusive education system-Equity and Inclusive Education Strategy (2009). In addition, the OME Policy 
Program Memorandum, No. 119, (2013) requires that all Ontario school boards create their own inclusive and equitable education policy. Policy No. 119 states that "culture is a way of knowing" and all students of all cultures should feel "safe, warm and welcomed and accepted, and inspired to succeed ..." (Ontario Ministry of Education, 2013, p. 1). The policy also acknowledges that "culture is a resource for learning" involving three dimensions: the institutional dimension of the administration and leadership, the personal dimension which focuses on the mindset of the educator, and the instructional dimension that includes knowledge of students and their needs (OME, 2013, p. 2).

Including the Indigenous narratives in our school curriculum and applying Culturally Responsive Schooling we may bridge the gap created by residential schooling and other colonial actions that exists between Indigenous and non-Indigenous graduates. In the year 2000, the Auditor General of Canada reported that First Nations graduates lag at least 25 years behind Canadian standards. History should be told in an honest and truthful manner to acknowledge the wrongdoings of the past and educate good citizens of the future.

\section{Conclusion}

Educators must cover a lot of history in a short time, so it is not possible for them or their students to become experts in the history of Indigenous people in Canada. However, because educators have such a limited amount of time to spend on $20^{\text {th }}$ century history, coverage of Indigenous history should include: 1) clear terminology and definitions of various Indigenous people, 2) various perspectives and narratives about events related to indigenous history, 3) a thorough coverage of treaty history, and 4) representation of the historical and intergenerational aftermath of the Residential schooling system. Learning about Indigenous issues in the Canadian context is a key component of anti-racist pedagogy and citizenship education and it should be exercised in a comprehensive manner. If the curriculum and educators spend a small amount of time covering these issues, then students may view it as not being a very important part of history. The Citizenship Education Framework (Appendix C) identifies all skills the government of Ontario deems necessary to becoming a good Canadian citizen. Active participation is seen as investigating controversial issues and voicing informed opinions on matters relevant to the community. Identity formation, according to the framework, involves developing a sense of connectedness to local, national, and global communities and considering and respecting other's perspectives. Indigenous people have been, are, and will be a part of our community. If we continue to teach our children a limited depiction of history told through one perspective, how we can guarantee the formation of good, active citizens in line with the Education Framework.

As stated by TRC, Canada has a history of racism which is deeply problematic as it creates unfair exclusions. Racisms are complex and there are multiple forms of racism which, when left unchecked by educators, can have disastrous consequences (Stanley, 2014, p. 4). This research shows the curriculum does not represent events related to Indigenous history in a thorough manner, which may be detrimental to students learning. If educators are to forge a new generation of anti-racists, they need to shine a light on the knowledge and meanings of 
those who have been and are being excluded (Stanley, 2014, p. 7). Such misrepresentations can be overcome with the help of anti-racist pedagogy that is about addressing the issues of racism and oppression openly without hesitation. Anti-racist pedagogy also aims to remember histories of oppression and discrimination, and offers such themes for open discussion (Blakeney, 2005). Anti-racist pedagogy can be practiced by every educator; however, the curriculum needs to provide teachers with adequate guidelines and references to address multiple racisms and to act on a true reconciliation constructively. The summary of some learning expectations I deem ideal to be present in Ontario Social Studies curriculum for grades 9-12 are included in Appendix E.

We must remember that Canada is party to legally binding international and local treaties that aimed to provide equity and rights protection to all members of our society. The United Nations Declaration on the Rights of Indigenous Peoples (UNDRIP) was adopted by the General Assembly on Thursday, 13 September 2007. On 12 November 2010 Canada officially endorsed the declaration but without changing its position which was 'aspirational' (Toensing, 2011). As Battiste (2008) stated in her presentation:

The real empowerment comes when non-First Nations peoples and their children, society, come to understand the purpose, intention, and legal obligations of national and international treaties. It is not just an issue of political debate; it is a legal institutional and political reality in Canada and must be upheld for all the other Canadian values to be held (p.7).

We need to consider what is represented in the curriculum so as not to lose these stories to the past. We are driven by an ethical responsibility to speak up for the many victims of discrimination, racism, oppression, and hate who are no longer with us today.

\section{References}

Alfred, T. (2005). Wasase: Indigenous pathways of action and freedom. Peterborough, ON: Broadview Press.

Assembly of First Nations. (1988). Tradition and Education: Towards a Vision of Our Future. Ottawa: Assembly of First Nations.

Auditor General. (2000). Report of the Auditor General to the House of Commons. Chapter 4: Indian and Northern Affairs Canada - Elementary and Secondary Education. Ottawa: Minister of Public Works and Government Services.

Barman, J., Hebert, Y, \& McCaskill, D. (1986). The Legacy of the Past: An Overview. In J. Barman, Y. Hebert \& D. McCaskill (Eds.). Indian Education in Canada: Volume 1: The Legacy. (Pp.1-22) Vancouver, BC: UBC Press. 
Battiste, M. (1998). Enabling the Autumn Seed: Toward a decolonized approach to aboriginal knowledge, language, and education. Canadian Journal of Native Education 22(1), 16-27.

Battiste, M. (2004). Animating Sites of Postcolonial Education: Indigenous Knowledge and the Humanities. Plenary Address at annual conference of the Canadian Society for the Study of Education, Manitoba, Saskatchewan, May 29. Retrieved 20 March, 2016 from http://www.usask.ca/education/people/battistem/pdf/csse battiste.pdf

Battiste, M. (2005). State of Aboriginal Learning. Saskatoon: Canadian Council on Learning.

Battiste, M. (2008). Animating Indigenous Knowledge in Education: From Resilience to Renaissance. Presentation at World Indigenous Peoples' Conference on Education, Melbourne, Australia, December 7-11. Retrieved from http://www.usask.ca/education/people/battistem/WIPCE-2008-Keynote.pdf

Battiste, M. (2013). Decolonizing education: Nourishing the learning spirit. Saskatoon: Purich.

Battiste, M. \& Barman, J. (1995). First Nations Education in Canada: The Circle Unfolds. Vancouver, BC: UBC Press.

Blakeney, A. (2005). Antiracist pedagogy: definition, theory, and professional development. Journal of Curriculum and Pedagogy. 2(1), 119-132.

Canada. (2002). Our Children: Keepers of the Sacred Knowledge - Final Report of the Minister's National Working Group on Education. Ottawa: Minister of Indian and Northern Affairs.

Carr-Stewart, S. (2001). A Treaty Right to Education. Canadian Journal of Education 26(2), 125-143. Retrieved 30 December 2017 from http://www.afn.ca/uploads/files/education/8. 2001 carrstewart treaty right to education.pdf

Castagno, A., \& Brayboy, B. (2008). Culturally responsive schooling for indigenous youth: A review of the literature. Review of Educational Research, 78(4), 941-993.

Corbiere, A. (2000). Reconciling Epistemological Orientations: Toward a Wholistic Nishaabe (Ojibwe/Odawa/Potowantomi) Education. Canadian Journal of Native Education. 24(2), 113-119.

Daschuk, J. (2013). Clearing the plains: Disease, politics of starvation and the loss of Aboriginal life. Regina: University of Regina Press.

Dei, G. (2013). Critical perspectives on indigenous research. Social Studies. 9(1), 27-38. 
Doige, L. (1997). A Missing Link: Between Traditional Aboriginal Education and the Western System of Education. Canadian Journal of Native Education. 27(2), 144-160.

Donald, D. (2009). Forts, curriculum, and Indigenous Métissage: Imagining decolonization of Aboriginal-Canadian relations in educational contexts. First Nations Perspectives, 2(1), 1-24.

Faries, E. \& Pashagumskum, S. (2002). A History of Quebec and Canada. Iqaluit, Nunavut: Nortext Publishing.

Gay, G. (2002). Preparing for culturally responsive teaching. Journal of Teacher Education, 53(2), 106-116.

Hampton, E. (1995). Towards a Redefinition of Indian Education. In M. Battiste \& J. Barman (Eds.). First Nations Education in Canada: The Circle Unfolds. Vancouver, BC: UBC Press.

Indigenous and Northern Affairs of Canada. (1998). Address by the Honourable Jane Stewart Minister of Indian Affairs and Northern Development on the occasion of the unveiling of Gathering strength - Canada`s Aboriginal Action Plan. Ottawa, Ontario. Retrieved 20 December 2016 from https://www.aadncaandc.gc.ca/eng/1100100015725/1100100015726

Laenui, P. (2000). Processes of Decolonization. In Battiste, M. (Ed.). Reclaiming indigenous voice and vision, 150-160. Vancouver: UBC Press.

LeBlanc, D. (2012). Envisioning a Contemporary Indigenous Curriculum in Ontario. Public Policy \&Governance Review. 3(1), 47-67. Retrieved 17 February, 2016 from https://ppgr.files.wordpress.com/2012/01/ppgr-full-text-vol3iss12.pdf

Library and Archives Canada. (2008). Introduction: The League of Indians of Canada. Retrieved 24 March, 2016 from http://www.collectionscanada.gc.ca/008/001/0080015000-e.php?\&e=1\&brws=1\&st=Aboriginal\%20Documentary\%20Heritage: \%20Historical\%20Collections\%20of\%20the\%20Canadian\%20Government\&ts nbr=1\&.

Longboat, D. (1987). First Nations Control of Education: The Path to our Survival as Nations. In J. Barman, Y. Hebert, \& D. McCaskill (Eds). Indian Education in Canada: Volume 2: The Challenge, 22-42. Vancouver, BC: UBC Press.

Maina, F. (1997). Culturally Relevant Pedagogy: First Nations education in Canada. Canadian Journal of Native Education. 27(2), 293-314.

Minister of Indian Affairs and Northern Development. (1997). Gathering Strength: Canada's Aboriginal Action Plan. Retrieved 21 March 2016 from www.ahf.ca/downloads/gathering-strength.pdf 
Office of the Premier. (2016). Ontario Implementing New Indigenous Training and Education Requirements. News release, Feb. 17, 2016. Retrieved 22 March, 2016 from https://news.ontario.ca/opo/en/2016/02/ontario-implementing-new-indigenoustraining-and-education-requirements.html

Ontario Ministry of Education. (2013). Culturally Responsible Pedagogy (Capacity Building Series, Secretariat Special Edition \#35). Retrieved from https://www.edu.gov.on.ca/eng/literacynumeracy/inspire/research/CBS ResponsiveP edagogy.pdf

Ontario Ministry of Education. (1975). People of Native Ancestry: A Resource Guide for the Primary and Junior Divisions. Toronto, Ontario: Ministry of Education.

Ontario Ministry of Education. (1981). People of Native Ancestry: Curriculum Guideline for the Senior Division. Toronto, Ontario: Ministry of Education.

Ontario Ministry of Education. (1991). Native Studies: Curriculum Guideline for the Intermediate Division. Toronto, Ontario: Ministry of Education.

Ontario Ministry of Education. (1991). The Ontario Curriculum Grades 9 and 10: Native Studies. Toronto, Ontario: Ministry of Education.

Ontario Ministry of Education. (2000). The Ontario Curriculum Grades 11 and 12: Native Studies. Toronto, Ontario: Ministry of Education.

Ontario Ministry of Education. (2015). The Ontario curriculum grades 11 and 12: Canadian and World Studies.

Ontario Ministry of Education. (2013). The Ontario curriculum grades 9 and 10: Canadian and World Studies.

Part, B. (2008). Developing a Culturally Responsive School Division. Final Report. Retrieved from http://schools.spsd.sk.ca/cgtrenewal/wp-content/uploads/2011/02/Developinga-Culturally-Responsive-School-Division-final-report.doc.

Persson, D. (1986). The Changing Experience of Indian Residential Schooling: Blue Quills, 1931-1970. In J. Barman, Y. Hebert, \& D. McCaskill (Eds.). Indian education in Canada: Volume 1: The Legacy. (Pp.150-168). Vancouver, BC: UBC Press.

Porter, J. (2015). Sterilization of indigenous women an act of genocide, new book says. CBC News. Retrieved 12 March 2016 from http://www.cbc.ca/news/canada/thunderbay/sterilization-of-indigenous-women-an-act-of-genocide-new-book-says-1.3205816

Pitt, A., \& Britzman, D. (2003). Speculations on qualities of difficult knowledge in teaching and learning: An experiment in psychoanalytic research. Qualitative Studies in Education, 16(6), 755-776. 
Robertson, H. (2003). In Canada: Decolonizing schools. Phi Delta Kappan, 84(7), p.552.

Saskatchewan Ministry of Education. (2009). Treaty Essential Learnings. Retrieved fromhttp://www.education.gov.sk.ca/treaty-education/survey2010

Smith, M. (2001). Relevant Curricula and School Knowledge: New Horizons. In Aboriginal Education in Canada: A Study of Decolonization. (pp.77-88). Mississauga, Ontario: Canadian Educators Press.

Stanley, T. J. (2014). Antiracism without guarantees: A framework for rethinking racisms in schools. Critical Literacy: Theories and Practices8(1), 4-19.

The Native Women's Association of Canada (NWAC). (2016). Retrieved from www.nwac.ca/

Toensing, G. (2011). Political Party! Celebrating UNDRIP and Indigenous Culture in Montreal. Indian Country Today Media Network.com. Retrieved from http://indiancountrytodaymedianetwork.com/2011/09/13/political-party-celebratingundrip-and-indigenous-culture-montreal-53604

Truth and Reconciliation Commission of Canada. (2015). Calls for action. Retrieved from: http://nctr.ca/reports.php

Truth and Reconciliation Commission of Canada. (2015). Honouring the Truth, Reconciling for the Future. Summary of the Final Report of the Truth and Reconciliation Commission of Canada. Retrieved from: http://www.trc.ca/websites/trcinstitution/File/2015/Honouring the Truth_Reconcilin $\mathrm{g}$ for the Future July 23 2015.pdf

Ward, D. (2015). Indigenous versus Aboriginal, which one to use? National News. February 19, 2015. Retrieved from http://aptn.ca/news/2015/02/19/indigenousversus-aboriginal-one-use/

\section{Appendix A: The List of Courses Analyzed}

For this study the following two curriculum documents were analyzed: 
5. Ontario Ministry of Education. (2015). The Ontario curriculum grades 11 and 12: Canadian and World Studies.

6. Ontario Ministry of Education. (2013). The Ontario curriculum grades 9 and 10: Canadian and World Studies.

Out of which five courses that are relevant and should include sections on the history of Indigenous people in Canada were researched:

- World History Since 1900: Global and Regional Interactions (CHT3O).

- Canadian History Since World War 1, both academic and applied (CHC2D and CHC2P).

- Civics and Citizenship (CHV2O).

- Adventures in World History (CHM4E).

\section{Appendix B: Analysis Table}

\section{TABLE B1: REPRESENTATION OF HISTORY OF INDIGENOUS PEOPLE IN SOCIAL STUDIES} ONTARIO CURRICULUM (GRADES 9-12)

\begin{tabular}{|c|c|}
\hline $\begin{array}{l}\text { Course (Total } \\
66 \text { pages) }\end{array}$ & $\begin{array}{l}\text { Overall and specific learning expectations that contain themes related to } \\
\text { indigenous discrimination (including provided examples and prompt } \\
\text { questions--nearly } 100 \text { expectations in total) }\end{array}$ \\
\hline \multirow{10}{*}{$\begin{array}{l}\text { Canadian } \\
\text { History Since } \\
\text { World War } 1 \\
\text { academic } \\
\text { (CHC2D)-18 } \\
\text { pages }\end{array}$} & $\begin{array}{l}\text { A1.4 Use a concept map to help assess consequences of residential schools } \\
\text { for aboriginal people. Which concept of historical thinking might help you } \\
\text { analyze the Canadian government decision to forcibly relocate Inuit people in } \\
\text { the 1950s? }\end{array}$ \\
\hline & $\begin{array}{l}\text { A1.7 Suggests writing an essay (as development of communication skills) on } \\
\text { turning points for Aboriginal people since } 1960 \text {. }\end{array}$ \\
\hline & $\begin{array}{l}\text { A2.3 Which historical events might help you more fully understand the issues } \\
\text { involved in current debates over resource development projects in Canada } \\
\text { and First Nations treaty rights? }\end{array}$ \\
\hline & B1.1 Analyze historical statistics on aboriginal populations. \\
\hline & $\begin{array}{l}\text { B2.4 What impact did the League of Indians have on the lives of Aboriginal } \\
\text { people in Canada? }\end{array}$ \\
\hline & $\begin{array}{l}\text { B2.5 Describe attitudes and significant actions (residential schools, } \\
\text { restrictions imposed by the Indian Act). }\end{array}$ \\
\hline & $\begin{array}{l}\text { B3. Predominant attitudes towards First Nations, Inuit, and Métis. B3.1 The } \\
\text { League of Indians` contribution to society. }\end{array}$ \\
\hline & C1.4 What amendments were made to the Indian Act in the 1930s? \\
\hline & D2.1 Describe social conflict (e.g.: Aboriginal title and land claims) \\
\hline & D2.2 Aboriginal activism. D2.3 Challenges facing Native women. \\
\hline
\end{tabular}




\begin{tabular}{|c|c|}
\hline & $\begin{array}{l}\text { D3. How Aboriginal people contributed to development of identity, } \\
\text { citizenship and heritage in Canada (1945-1982). D 3.1 The National Indian } \\
\text { Brotherhood. } \\
\text { D3.3 Explain some significant events, developments, and/or issues that } \\
\text { affected First Nations, Inuit, and/or Métis people in Canada during 1945-1982 } \\
\text { (forced relocation, the continuing operation of residential schools, the James } \\
\text { Bay project). } \\
\text { E1.4 Significance of } 2013 \text { `s ruling for the relationship between federal } \\
\text { government and both the Métis and non-status Indians in Canada? } \\
\text { E2.3 Identify key developments and issues that have affected the relationship } \\
\text { between the federal/provincial governments and First Nations, Métis and } \\
\text { Inuit people since 1982. } \\
\text { E 3.3 Forced relocation of Inuit families as an example of events influencing } \\
\text { history. }\end{array}$ \\
\hline $\begin{array}{l}\text { Canadian } \\
\text { History Since } \\
\text { World War 1-- } \\
\text { applied } \\
\text { (CHC2P) -15 } \\
\text { pages }\end{array}$ & $\begin{array}{l}\text { A1.5 Evaluating evidence of residential schools. Suggested as historical events } \\
\text { evaluation skills. } \\
\text { B1.4 Explosion in Halifax and Mi kmaq settlement. } \\
\text { B2.2 Why was it mandatory for status Indians to attend residential schools? } \\
\text { B2.3 The quality of life on reserves and residential schools. } \\
\text { D3.2 Explain some significant events, developments, and/or issues that } \\
\text { affected First Nations, Inuit, and/or Métis people in Canada during 1945- } \\
\text { 1982. } \\
\text { E2.2 Identify key developments and issues that have affected the relationship } \\
\text { between the federal/provincial governments and First Nations, Métis and } \\
\text { Inuit people since 1982. } \\
\text { E3.4 Describe some ways in which Canada has (since 1982) acknowledged } \\
\text { and commemorated past events with a focus on human tragedies that } \\
\text { occurred in Canada... }\end{array}$ \\
\hline $\begin{array}{l}\text { Civics and } \\
\text { Citizenship } \\
\text { (CHV2O)-11 } \\
\text { pages }\end{array}$ & $\begin{array}{l}\text { A1.7 "A petition calling for clean, safe water on First Nations reserve", } \\
\text { suggested as one of the ways to learn communication skills. } \\
\text { A2.4 Identify some careers in which civics and citizenship education might be } \\
\text { useful (Aboriginal community development worker). } \\
\text { B1.1 Describe some civic issues (Aboriginal treaty rights) } \\
\text { B1.2 What values underpin movements initiated by Aboriginal people such as } \\
\text { Idle No More? } \\
\text { B2. } 1 \text { What are the positions of different political parties on `inherent’ } \\
\text { Aboriginal rights? } \\
\text { B2.4 Why has Amnesty International been investigating missing and } \\
\text { murdered women in Canada? } \\
\text { C2.1 Issues of beliefs, values, and perspectives representation (First Nations, } \\
\text { Métis and Inuit people). } \\
\text { C2.2 Analyze the significance of recognition (e.g.: the National Aboriginal } \\
\text { Day). }\end{array}$ \\
\hline $\begin{array}{l}\text { World History } \\
\text { Since 1900: } \\
\text { Global and } \\
\text { Regional }\end{array}$ & $\begin{array}{l}\text { C3.1 How did residential schools in Canada and Australia violated the rights } \\
\text { of aboriginal peoples? }\end{array}$ \\
\hline
\end{tabular}




\begin{tabular}{|l|l|}
\hline $\begin{array}{l}\text { Interactions } \\
\text { (CHT3O) - 15 } \\
\text { pages }\end{array}$ & $\begin{array}{l}\text { D2.5 The role of religion in operating boarding schools for Indigenous } \\
\text { children in Canada. } \\
\text { D3.3 Describe some of the main social movements (aboriginal). } \\
\text { E3.3 Describe how human rights abuses have been addressed (Truth and } \\
\text { Reconciliation Commission in Canada). }\end{array}$ \\
\hline $\begin{array}{l}\text { Adventures in } \\
\text { World History } \\
\text { pages }\end{array}$ & $\begin{array}{l}\text { B1.2 Why did the Anishinaabe people regularly migrate between the Great } \\
\text { Lakes and the Atlantic Ocean? }\end{array}$ \\
$\begin{array}{l}\text { B1.5 What do traditional dwellings of First Nations or Inuit in North America } \\
\text { tell you about ...the natural resources they had access? } \\
\text { C1.1 European settlement and consequent disruption of indigenous } \\
\text { settlement cultures. What impact did colonialism have on the lives of } \\
\text { indigenous peoples in North/South America? }\end{array}$ \\
\hline
\end{tabular}

\section{Appendix C: Citizenship Education Framework}

Go to page 10 of the linked PDF document:

http://www.edu.gov.on.ca/eng/curriculum/secondary/canworld910curr2013.pdf 


\section{Appendix D: Copy of Political Accord}

\section{Political Accord \\ Between First Nations and the Government of Ontario}

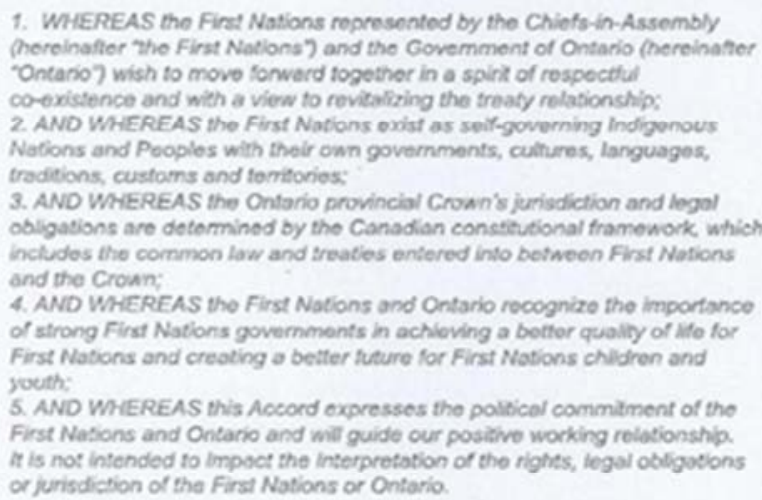

5. AND WMEREAS this Accord expresses the politicel commitment of the First Nations and Ontario and will guide our positivo working relationship. it is not intended to impoct the interpretation of the rights, legal obligution: or jurisdiction of the First Nations or Ontario

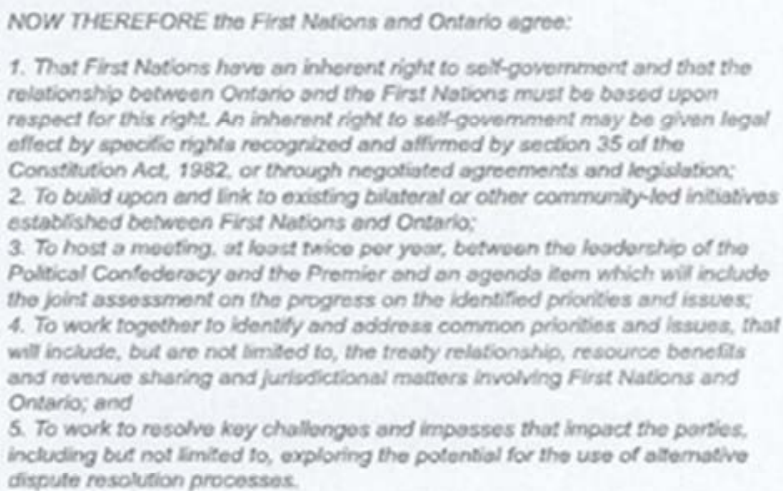

1. That First Notions have an inherent right to solf-government and that the relationship detween Ontario and the First Notions must be based upon respect for this righe An inherent right to self-govemment may be given legat effect by spocitio rights recognized and affirmed by section 35 of the Constitution Act, 1982, or through negotioted agreements and legislation 2. To bulld upon and link to existing bilaterat or other community-led inciatives established beiween First Nations end Ontario.

3. To host a meeting. at hast twice por yoar, between the lasdershio of the Poltical Confederacy and the Premier and on agends ilem which will include the joint assessment on the progress on the identified prionities and issues: 4. To work together to identily and address common prionities and lasues, that will include, but are not limited to, the treaty relationship, resource benefifts and revenue sharing and furlsdictional motters involving First Nations and Ontario; and

5. To work to resolve key challanges and imposses that impact the parties, inctuding but not limited to, exploring the potential for the use of attemative dispute fosolution procossins.

\section{Signed at the Legislative Assembly of Ontario, this 24th day of August, 2015.}

\section{Appendix E: Recommended Curriculum Expectation Regarding Indigenous Discrimination}

I would recommend inclusion of the following mandatory learning expectations:

a complete coverage of Residential Schooling system, including full history and analysis of its aftermath; a detailed and comprehensive coverage of Treaties signed by indigenous people and Federal government, suggesting analysis of the degree of fulfillment of the obligations and effects of non-negotiated interactions between the government and Indigenous people in current times; a thorough study of the findings of the Truth and Reconciliation Committee of Canada, offering practical guidelines for reconciliation activities appropriate to various grade levels. 